alternatively the provision of a 'warden' fire in addition to one lighting point and one 5-amp. plug socket for 1s. $3 d$. per week for 18 months. These proposals have been unanimously approved by the Electricity Committee, and will be put into operation as soon as the necessary approval has been obtained to the financing of the scheme. After the scheme has been approved by the Electricity Commissioners it is hoped that it will be put into operation. It is to be hoped that similar facilities will be made widespread by other undertakings throughout the country. Winter is immediately ahead, with much illness to come if the shelter-comfort problem is not dealt with promptly.

\section{Air Raid Precautions for Users of Ammonia}

THE Ministry of Home Security has recently issued a pamphlet on "Air-Raid Precautions to be taken by Users of Ammonia" (London : H.M. Stationery Office. 1d.). The extensive use which is now being made of anhydrous ammonia refrigerating plants makes the question an urgent one. The main precaution recommended is to keep stocks of anhydrous ammonia down to the absolute minimum. If the capacity of a given plant is sufficient to provide a reservoir, no reserve stocks at all should be kept. Where it is essential to keep additional supplies in cylinders, these should preferably be dispersed to protected positions in the open away from risk of fire and stored horizontally. If such a dispersal is impracticable, the cylinders should be placed in an angle of the walls of the building and suitably 'protected on the exposed sides. Precautions against the escape of ammonia from the refrigerating plant include the provision of sills around the area over which liquid ammonia may flow from a broken condenser coil ; and it is suggested that the condenser water should be kept running, as ammonia is readily soluble in water and the aqueous solution is less dangerous than the anhydrous liquid. In an emergency, the charge in the machine should be isolated by closing all possible stop valves. To facilitate this operation by possibly inexperienced personnel, the engine-room master-valves may be painted in striking colours. It is pointed out that cylinders to be emptied should be laid horizontally, so as to discharge the ammonia in liquid form, due care being taken to avoid burns by the splashing of the liquid.

\section{Electric Power Stations Underground}

As we see things at present, unless war can be banished from the earth we may have to revise our ideas completely as to underground power plant and underground shelters. The only really safe refuge in a great city assaulted from the air is a chamber far below the surface such as we find along some of the lowest tunnelling of the electric tubes, a level well below the maximum depth excavated by the comparatively feeble bomb of 1940. In the Electrical Times of September 26 it is stated that soon after the War of 1914-18 a few eminent consultants and power plant engineers sent the editor outline ideas of generating stations placed underground at low level. One of the difficulties which appeared insurmountable at that time was the supply of cooling water in large bulk at these depths. The inlet of water is easy enough, but what of the outlet? The case is a little less puzzling in that of oil-driven prime movers, but even these would strain the engineer's resources and ingenuity.

When the struggle at present raging reaches a settlement, inquiry may well be reopened. Excavations to a considerable depth and on a large scale may become essential, if only for providing an absolutely safe refuge for distracted people and hospital patients and staffs. Underground stations, too, are being used as air raid shelters. This is one stage of a difficulty which in time might become formidable; it will have to be considered along with the other problem of finding a safe lodging for the much-discussed electric power housc.

\section{British Rheologists' Club}

SINCE the outbreak of War, new and urgent problems concerning the flow and deformation properties of materials (rheology) have arisen in many industries and in research, and a group of British rheologists have therefore formed a club for mutual help and discussion. Prof. G. I. Taylor, Yarrow research professor of the Royal Society, has accepted. the presidency. The objects of the new Club are "to co-ordinate the activities of Rheologists in Britain during the War, to further the appreciation of the importance of rheology in industry and to facilitate the pooling of information (where it is desirable) with respect to problems and new methods of research". Membership of the Club is open to any individual working or interested in rheology who is resident anywhere in the British Empire, and there is a nominal subscription of five shillings per annum. Arrangements are in preparation for an inaugural meeting of the Club to be held at the National Institute for Research in Dairying, University of Reading, on November 16, when it is proposed to hold an informal discussion on a topic to be selected, followed by an inspection of rheological apparatus including some recent developments. Fullor details of the Club may be obtained from the honorary secretary, Dr. G. W. Scott Blair, c/o Institute of Physics, at the University, Reading, Berks.

\section{Primitive Art: Past and Future}

THE anthropologist, when confronted with some of the more extreme pronouncements of æsthetic judgment on the primitive artist, was at one time perhaps a little too apt to regard them as unwarranted apotheoses. of what was after all a phase and no more in a process of æsthetic development or 'evolution', differing in this relation in no essential from any other cultural element depending upon technical achievement. He was, however, so far justified in that each example of the artist's skill and taste was to be regarded with reference to its social and religious background; and while it might, and very often did, afford satisfaction to a judgment habituated to European canons, to award it the highest mark as 
an expression of resthetic principles, as, for example, in the better-known specimens of West African sculpture, seemed to attach a false value to characters which were, in historical perspective, faults of technique rather than an outcome, conscious or unconscious, of any theory of artistic balance, selection or composition. A saner method of approach to the products of primitive art was illustrated by Dr. Leonard Adam in a recent lecture delivered before the Royal Society of Arts ( $J$. Roy. Soc. Arts, June 28, 1940) in which he briefly directed attention to certain of the main principles of primitive art which emerge from its study in accordance with the evolutionary or cultural methods elaborated by the late Dr. A. C. Haddon, Prof. Franz Boas and others. Incidentally Dr. Adam stressed the interest and importance of the art of the American Indians of the north-west coast of America, which has suffered neglect in favour of the culturally less illuminating art of Africa.

The future of primitive art is, when properly understood, no less interesting than its past. It is true that in many parts of the world European impact has brought about degeneration; but experience in West Africa has shown that this is not inevitable. It was pointed out by Dr. Adam that modern ethnographical studies have demonstrated that early observers tended to overstress the static element in primitive culture. Art, however, like other cultural factors, has been subjected to a continuous process of change. Much of the so-called primitive art is in fact both highly sophisticated and 'evolved'. The result of such European guidance in West African education as has been formulated with understanding of native modes of thought has been to produce a native school of art, which not only in the traditional art of wood-carving, but also in other branches of artistic activity such as painting, is thoroughly African in conception, feeling, and atmosphere. It has survived or overcome the break with the social and religious factors upon which African art depended, but which vanished, or are vanishing, before European contacts. Hence, as Dr. Hanns Vischer pointed out from the chair on this occasion, this development indicates a line of advance in the present deplorable state of education in Africa-a beginning "to make grow . . . to liberate something which has been stifled under the thick crust of foreign knowledge acquired without real understanding".

\section{Rufford Village Museum}

RUFForD Village Museum, which was opened at Rufford Old Hall, a National Trust property in West Lancashire in July of last year as: "A Museum of Folk Culture and Industry : To illustrate and capture the spirit of the countryside" (to quote its constitution) is being developed by the honorary curator, Mr. Philip Ashcroft, jun., to be "an example for other districts to follow, so that in the future, each village or group of villages will have a museum to represent their life, history and culture". In addition to Baron Hesketh's extensive collection of old armoury and other relics of medieval life, Mr. Eric Hardy has drawn up lists of the local fauna and flora which will be exhibited above photographs, drawings, diagrams, etc., of wild life to encourage people to preserve as well as observe the wild life of the parish. This happens to be unusually rich, for the flora includes flowering rush, flowering fern, arrowhead, yellow waterlily, water soldier, bladderwort and nearly a thousand other plants; there is a list of twentytwo mammals for the parish and F. A. H. Hall and E. Hardy have drawn up a list of 101 bird records, including sixty nesting species - a third of the British records. The Museum itself is a historic old timbered hall, the restored part of which dates from the seventeenth century.

\section{Research in Social Relations in Industry}

Mr. H. VALDER, of Hamilton, New Zealand, has endowed for five years a research fellowship in social relations in industry at Victoria University College, Wellington, N.Z. Mr. Valder has himself done original work in investigating problems of industry, more especially those concerning the relation of capital and labour, and he believes that the work can be carried further by a man with scientific knowledge. To ensure that the investigator may be independent, the work is to be done under the ægis of the Victoria University College Council, and the appointment will carry with it the privileges of a professorial chair in the College. The salary offered is $£ 1,000$ a year (N.Z. currency) for five years. Applications from candidates should be sent to the Registrar of the College.

\section{Forestry Investigations in India}

THE activities of the Forest Research Institute at Dehra Dun, India, are summarized in a report entitled "Forest Research in India and Burma, Part 1, 1938-39". The work of the various branches of the Institute is described and the report forms a record of a large amount of useful work carried out in the interests of the State. Apart from research work, an enormous number of queries relating to the utilization of various forest products has kept the staff extremely busy during the year. It is noteworthy that all the provinces of India now employ an officer solely dealing with sylvicultural problems. The co-ordination of this work and advising on statistical requirements, in order to make the best use of the researches going on, have taxed the Sylvicultural Branch of the Institute severely.

It is not possible to make more than passing reference to a few of the programmes of work that are being carried out. The destruction of timbers by termites and by fungi is one of great importance, and this work is closely linked with problems of the seasoning and preservation of woods of many kinds. The paper-pulp section is another activity of great importance and promise, and questions connected. with the manufacture of paper and plywood were probably the most numerous of all. The report itself, it may be added, is printed on paper made at the Institute from Saccharum arundinaceum. The cultivation of drugs is another aspect of work that 